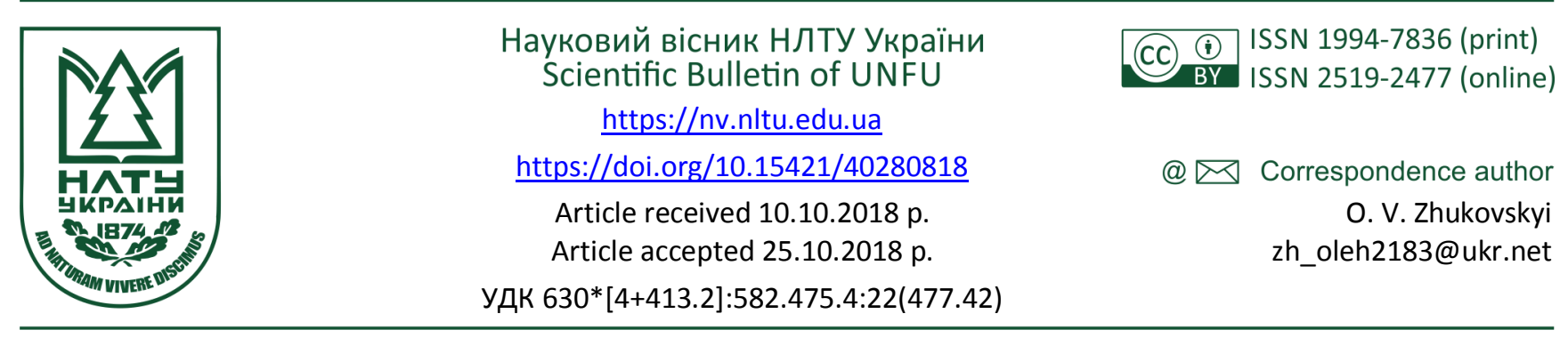

О. В. Жуковський ${ }^{1}$ О. О. Орлов ${ }^{1}$, О. В. Зборовська ${ }^{1}$, О. В. Струтинський ${ }^{1}$ В. В. Шевчук ${ }^{1}$, Р. А. Карчевський', І. Т. Гулик', О. В. Левківський

${ }^{1}$ Поліський філіал УкрНДІЛГА ім. Г. М. Висоиького, с. Довжик, Украйна ${ }^{2}$ ДП "Житомирське лісове господарство", м. Житомир, Україна

\title{
САНІТАРНИЙ СТАН СОСНОВИХ ДЕРЕВОСТАНІВ ПІСЛЯ ПРОВЕДЕННЯ САНІТАРНИХ РУБОК ВИБІРКОВИХ, У КУЛІСАХ ТА ДРІБНОКОНТУРНИХ ДІЛЯНКАХ В ОСЕРЕДКАХ УРАЖЕННЯ КОРОЇДОМ ВЕРХІВКОВИМ
}

\begin{abstract}
Дослідження проведено у Житомирському Поліссі впродовж 2017 р. Проаналізовано санітарний стан деревостанів сосни звичайної в осередках ураження короїдом верхівковим після проведення санітарних рубок вибіркових (СРВ), а також окремо - у кулісах і дрібноконтурних ділянках. Виявлено, що основним шкідником, який зумовлює всихання досліджених сосняків, $є$ короїд верхівковий. Продемонстровано, що в соснових кулісах та дрібноконтурних ділянках найбільша кількість обстежених деревостанів - сильно ослаблені (58,5\%), всихаючі - 29,2 \%, ослаблені - 7,7 \% та мертві - 4,6 \%. Особливо варто наголосити, що серед досліджуваних сосняків немає здорових деревостанів. Встановлено, що після проведення СРВ максимальна частка сильно ослаблених сосняків становила 42,7 \%, що є меншим порівняно з відповідним показником для куліс $\mathrm{i}$ дрібноконтурних ділянок. Водночас, частка ослаблених насаджень значно більша після проведення СРВ - 21,3 \%, а мертвих - значно менша (2,7 \%) порівняно з відповідним показником для куліс та дрібноконтурних ділянок. Зроблено висновок про те, що санітарні рубки вибіркові в осередках ксилофагово-офіостомового комплексу не дають очікуваного ефекту, і за один-два вегетаційні періоди санітарний стан соснових деревостанів значно погіршується, як і санітарний стан сосняків у кулісах та дрібноконтурних ділянках. Обгрунтовано пропозицію про внесення змін у чинні нормативні документи для ведення лісового господарства через гостру дію ксилофагово-офіостомового комплексу.

Ключові слова: сосна звичайна; всихання; стовбурові шкідливі комахи; категорія санітарного стану; лісогосподарські за-
\end{abstract} ходи.

Вступ. За останні роки у лісових екосистемах Полісся та Лісостепу України активізувалися лісопатологічні процеси, які призводять до масового всихання деревостанів сосни звичайної (Pinus sylvestris L.). Небачені раніше потужне розмноження та агресивність деяких видів стовбурових шкідників, перше місце серед яких належить короїду верхівковому (Ips acuminatus (Gyllenhal, 1827)), стали вагомими факторами дестабілізації лісів і лісокористування. Результати як наукових досліджень, так і відомчих обліків демонструють, що санітарна ситуація у сосняках продовжує ускладнюватися.

Основними заходами вирішення проблеми спалаху стовбурових шкідників є лісогосподарські (санітарні рубки). Санітарні рубки повинні бути спрямовані у двох напрямках. Найважливішим є першочергове вилучення свіжозаселених шкідниками дерев у найкоротші терміни - для зменшення і взяття під контроль чисельності популяцій короїда верхівкового та смолюха жерднякового соснового (Pissodes piniphilus (Herbst, 1797)). У другу чергу потрібно вилучати патологічний відпад (мертва деревина), оскільки він $є$ субстратом для розмноження вторинних і технічних шкідників.

Мета дослідження - встановити санітарний стан соснових деревостанів, в яких проведено санітарну рубку вибіркову, а також тих, які зростають у кулісах і дрібноконтурних ділянках без санітарних рубок вибіркових.

\section{Інформація про авторів:}

Жуковський Олег Валерійович, наук. співробітник. Email: zh_oleh2183@ukr.net

Орлов Олександр Олександрович, канд. біол. наук, ст. наук. співробітник, зав. лаб. радіаційної екології лісу.

Email: orlov.botany@gmail.com

Зборовська Ольга Володимирівна, канд. с.-г. наук, ст. наук. співробітник. Email: olga.zborovska@ukr.net; https://orcid.org/00000003-1649-0297

Струтинський Олександр Валентинович, наук. співробітник. Email: alex.str777@gmail.com

Шевчук Віктор Васильович, канд. с.-г. наук, ст. наук. співробітник, директор. Email: polysskiy_branch@ukr.net

Карчевський Руслан Анатолійович, директор. Email: info@ztlis.com.ua

Гулик Ігор Теодорович, наук. співробітник. Еmail: gulikigor@gmail.com

Левківський Олексій Володимирович, провідний інженер. Email: polysskiy_branch@ukr.net

Цитування за ДСтУ: Жуковський О. В., Орлов О. О., Зборовська О. В. та ін. Санітарний стан соснових деревостанів після проведення санітарних рубок вибіркових, у кулісах та дрібноконтурних ділянках в осередках ураження короїдом верхівковим. Науковий вісник НЛТУ України. 2018, т. 28, № 8. С. 87-91.

Citation APA: Zhukovskyi, O. V., Orlov, O. O., Zborovska, O. V., et al. (2018). Sanitary status of pine stands after selective sanitary cuttings, on the narrow strips and small-plot areas in the Ips acuminatus pockets. Scientific Bulletin of UNFU, 28(8), 87-91.

https://doi.org/10.15421/40280818 
Об'єкти і методи дослідження. Упродовж жовтнягрудня 2017 р. досліджено санітарного стану соснових деревостанів в осередках ураження короїдом верхівковим після проведення санітарних рубок вибіркових, а також окремо - у кулісах і дрібноконтурних ділянках. Дослідження проведено у ДП "Новоград-Волинське дослідне лісомисливське господарство", ДП "Житомирське лісове господарство", ДП "Білокоровицьке лісове господарство", ДП "Лугинське лісове господарство", ДП "Городницьке лісове господарство" Житомирського обласного управління лісового і мисливського господарства (рис. 1).

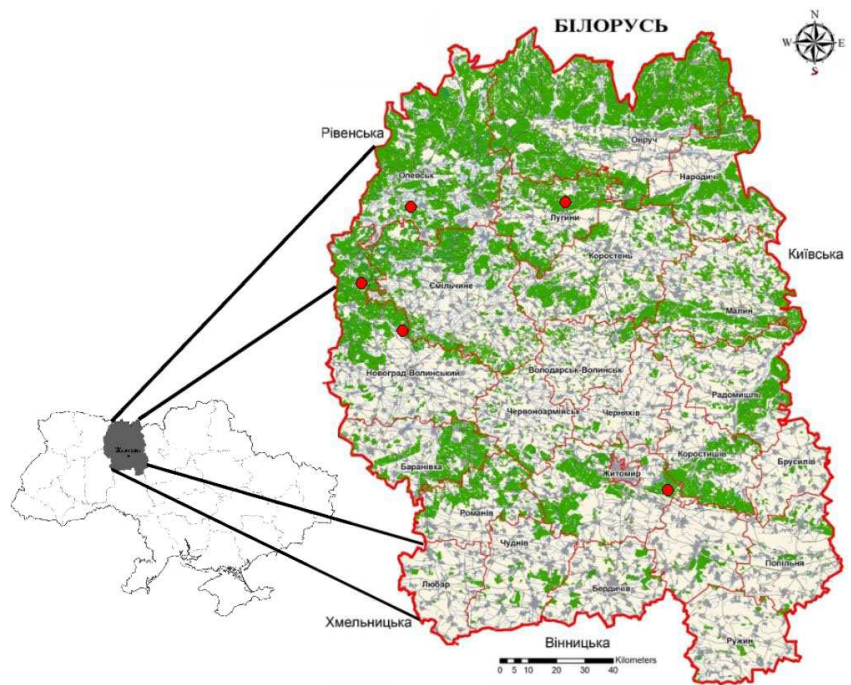

Рис. 1. Розташування об'єктів досліджень (Житомирська область, Україна)

Загальна площа обстежених ділянок - змінювалася у діапазоні 311,1 га (75 шт.), повнота деревостанів після проведення СРВ коливалася у діапазоні від 0,1 до 0,5. Загальна площа обстежених куліс і дрібноконтурних ділянок становила 86,8 га (65 шт.), ширина куліс змінювалась в діапазоні від 10 до 70 м. Куліси і дрібноконтурні ділянки утворилися після проведення рубок головного користування або санітарних рубок суцільних 1-6 років тому.

Ксилофагово-офіостомовий комплекс в осередках всихання соснових деревостанів є складним. Найбільш шкодочинним та поширеним є короїд верхівковий. Окрім нього траплялися: короїд шестизубчастий (Ips sexdentatus (Boerner, 1776)), короїд родиннохідний (Orthotomicus laricis (Fabricius, 1792)), лубоїд малий сосновий (Blastophagus minor (Hartig, 1834)), лубоїд великий сосновий (Blastophagus piniperda (Linnaeus, 1758)), златка синя соснова (Phaenops cyanea (Fabricius, 1775)), вусач сірий довговусий (Acanthocinus aedilis (Linnaeus, 1758)) i вусач чорний сосновий (Monochamus galloprovincialis (Olivier, 1795)). Вони, окрім прямого пошкодження дерев, також переносять діаспори офіостомових грибів, які є збудниками трахеомікозу хвойних.

Науково-дослідні роботи здійснено у соснових деревостанах підприємств маршутним методом у систематичному порядку. Обліки, виміри, визначення та описи на досліджуваних об'єктах виконано за загальноприйнятими методиками лісівництва, лісової таксації і лісової ентомологіï (Pravyla, 2016; Anuchin, 1982; Krasnov et al., 2013; Meshkova, 2010; Materially, 1987). Лісопатологічні обстеження всихаючих сосняків здіймнено шляхом закладання пробних площ згідно з СОУ 02.02-37-
476: 2006 "Площі пробні лісовпорядні. Метод закладання" (Ploshchi probni lisovporiadni, 2006).

Для визначення шкідників та хвороб використано довідкову літературу (Krasnov, 2011; Padii, 1993; Shevchenko \& Tciliurik, 1986; Lisovyi \& Chaika, 2008). Оцінено санітарний стан дерев згідно з "Санітарними правилами в лісах України" (Pravyla, 2016): дерева I категорії санітарного стану - без ознак ослаблення; II ослаблені; III - сильно ослаблені; IV - дерева, що всихають; V - свіжий сухостій; VI - старий сухостій. За їх співвідношенням розраховували загальний індекс санітарного стану насадження кожної дослідженої ділянки, який визначали за формулою

$$
I=\sum_{j=1}^{6} j \cdot n_{j} / \sum_{j=1}^{6} n_{j}
$$

де $n_{1, \ldots}, n_{6}-$ кількість дерев відповідної категорії санітарного стану.

Санітарний стан визначали за такою шкалою: здоровий (індекс стану - 1,00-1,50), пошкодження деревостану відсутні; ослаблений $(1,51-2,50)$, ступінь пошкодження деревостану слабкий; сильно ослаблений $(2,51-$ $3,50)$, ступінь пошкодження деревостану середній; всихаючий $(3,51-4,50)$, ступінь пошкодження деревостану сильний; мертвий $(4,51-6,00)$, ступінь пошкодження деревостану дуже сильний (Pasternak, 1990).

Результати дослідження та їх обговорення. Під час проведення рубок головного користування чи санітарних рубок суцільних згідно з вимогами чинних нормативних документів у соснових деревостанах утворюються дрібноконтурні ділянки 3 площею до 0,1-0,2 га, або куліси завширшки 10-70 м, а під час санітарних рубок вибіркових - низькоповнотні насадження (повнота 0,4-0,5) та рідини (рідколісся 3 повнотою 0,1-0,3). Унаслідок зазначених лісогосподарських заходів у цих деревостанах значно збільшується освітленість крони та стовбура дерев, тому вони ослаблюються і уражаються стовбуровими шкідливими комахами. Як відомо, основним стовбуровим шкідником нині короїд верхівковий. Він є світлолюбною комахою, тому наведені вище соснові деревостани для нього $є$ привабливою кормовою базою. Особливо варто наголосити, що навіть у сосняках, де було проведено СРВ, короїд верхівковий залишається у певній кількості, оскільки виявлення свіжозаселених короїдом дерев на початковій стадії ураження значно ускладнене.

За результатами аналізу отриманих даних досліджено розподіл обстежених сосняків, які зростають у кулісах і дрібноконтурних ділянках, за санітарним станом. Аналіз даних рис. 2 демонструє, що найбільше соснових деревостанів в обстежених кулісах та дрібноконтурних ділянках є сильно ослабленими (58,5 \% від загальної кількості), всихаючими - 29,2 \% ділянок, ослабленими $-7,7 \%$, а мертвими - 4,6\% ділянок. Варто особливо наголосити, що серед досліджуваних сосняків немає здорових деревостанів.

Окремо проаналізовано вплив розташування досліджених соснових куліс та дрібноконтурних ділянок відносно сторін світу на їх санітарний стан. Виявлено відсутність достовірного впливу згаданого фактора на санітарний стан сосняків. У соснових деревостанах, в яких було проведено санітарні рубки вибіркові, спостережено кращий санітарний стан порівняно $з$ кулісами та 
дрібноконтурними ділянками, оскільки уражені шкідливими комахами дерева були в основному видалені.

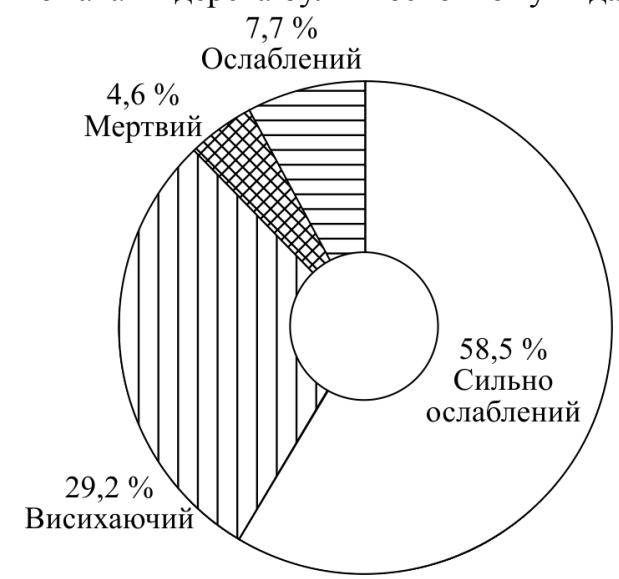

Рис. 2. Розподіл досліджених соснових куліс і дрібноконтурних ділянок за санітарним станом

За результатами аналізу отриманих даних досліджено розподіл обстежених сосняків, де було проведено санітарні рубки вибіркові, за санітарним станом. Дані рис. 3 наочно свідчать про максимальну частку сильно ослаблених сосняків після проведення СРВ (42,7\%), яка $є$ меншою порівняно з відповідним показником для куліс та дрібноконтурних ділянок. Натомість частка ослаблених деревостанів була значно більшою у сосняках після СРВ - 21,3\%, а мертвих - значно менша - 2,7 \%, порівняно з відповідним показником для куліс та дрібноконтурних ділянок.

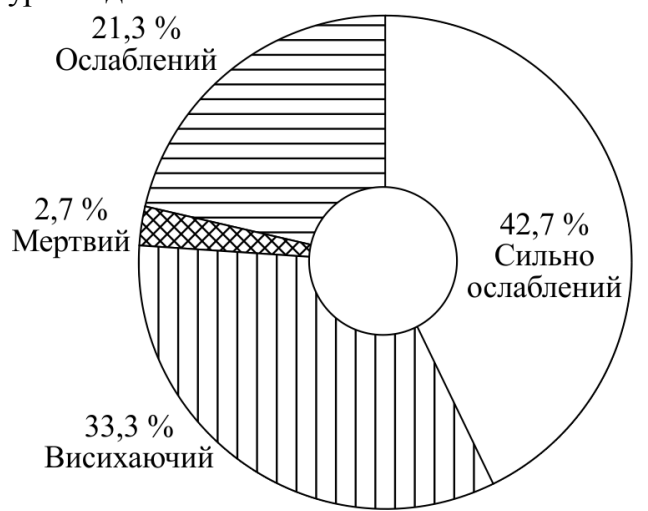

Рис. 3. Розподіл соснових деревостанів, де проводили санітарні рубки вибіркові, за санітарним станом

Загалом частка ослаблених і сильно ослаблених соснових деревостанів після проведення СРВ становила $64,0 \%$, а частка всихаючих і мертвих - 36,0\%. Серед досліджених сосняків після проведення СРВ, як і в кулісах та дрібноконтурних ділянках, відсутні здорові деревостани. Аналізуючи санітарний стан сосняків, встановлено, що СРВ проводили у різні місяці та пори року (табл. 1). Виявлено, що у сосняках після проведення СРВ впродовж одного вегетаційного періоду санітарний стан деревостанів істотно погіршився - 3 ослабленого до всихаючого, що свідчить про дуже низьку ефективність здійсненого заходу.

Окрім цього, виявлено, що у багатьох випадках санітарний стан сосняків після проведення СРВ швидко погіршувався, що змусило лісівників робити довідводи у вражених короїдами соснових деревостанах та проводити другий прийом СРВ на вже пройдених СРВ ділянках. Така практика проведення рубок санітарних вибіркових (із зниженням повноти до 0,1 , як прописано в чинних Санітарних правилах України) є негативною i несе загрозу повної загибелі деревостанів. 3 огляду на це більш дієвими і виваженими вважаємо Тимчасові рекомендації щодо проведення першочергових заходів у соснових лісах, пошкоджених короїдами (Rekomendatsii, 2017), які розробив колективом науковців УкрНДІЛГА під керівництвом проф. В. Л. Мєшкової, за якими повноту деревостанів для рубок санітарних суцільних визначено 0,4.

Табл. 1. Санітарний стан соснових деревостанів, де проводили СРВ, за сезонами (станом на жовтень-грудень 2017 р.)

\begin{tabular}{|c|c|c|c|c|}
\hline $\begin{array}{c}\text { № } \\
\text { 3/п }\end{array}$ & $\begin{array}{c}\text { Сезон } \\
\text { СРВ }\end{array}$ & $\begin{array}{c}\text { Дати прове-- } \\
\text { дення СРВ }\end{array}$ & $\begin{array}{c}\text { Середній індекс } \\
\text { санітарного ста- } \\
\text { ну деревостану }\end{array}$ & $\begin{array}{c}\text { Санітарний стан } \\
\text { деревостану }\end{array}$ \\
\hline 1 & $\begin{array}{c}\text { Зима/ } \\
\text { весна }\end{array}$ & $(01.01 .-14.04)$. & 3,6 & Всихаючий \\
\hline 2 & Літо & $(15.06 .-31.08)$. & 3,5 & $\begin{array}{c}\text { Сильно } \\
\text { ослаблений }\end{array}$ \\
\hline 3 & Осінь & $(01.09 .-30.11)$. & 2,9 & $\begin{array}{c}\text { Сильно } \\
\text { ослаблений }\end{array}$ \\
\hline 4 & Зима & $(01.12 .-20.12)$. & 2,4 & Ослаблений \\
\hline
\end{tabular}

Примітка: $з$ 15.04. по 14.06. - сезон тиші (санітарні рубання не проводяться).

Для детальнішого аналізу усереднено частки дерев за категоріями санітарного стану (табл. 2). Так, в ослаблених сосняках частка дерев I та II категорій санітарного стану разом становить $67,2 \%$, також наявні дерева V i VI категорій санітарного стану, їх частка разом становить 2,2 \%. Треба зазначити, що на цих деревах відсутні ознаки життєдіяльності первинних стовбурових шкідливих комах, зокрема і короїда верхівкового, а головними причинами $є$ природні процеси відпаду.

Табл. 2. Розподіл дерев сосни звичайної за категоріями санітарного стану у соснових кулісах та дрібноконтурних ділянках

\begin{tabular}{|c|c|c|c|c|c|c|c|}
\hline \multirow{2}{*}{\begin{tabular}{l}
\multirow{2}{*}{ № } \\
3/п
\end{tabular}} & \multirow{2}{*}{$\begin{array}{c}\text { Санітарний стан } \\
\text { деревостану }\end{array}$} & \multicolumn{5}{|c|}{ Частка дерев за категоріями } \\
\cline { 3 - 8 } & & I & II & III & IV & V & VI \\
\hline 1 & Ослаблений & 12,4 & 54,8 & 22,9 & 7,7 & 1,9 & 0,3 \\
\hline 2 & Сильно ослаблений & 2,7 & 31,4 & 39,0 & 15,3 & 6,7 & 4,9 \\
\hline 3 & Всихаючий & 0,7 & 10,6 & 30,7 & 15,8 & 23,9 & 18,4 \\
\hline 4 & Мертвий & 0 & 9,2 & 17,3 & 8,9 & 24,0 & 40,6 \\
\hline
\end{tabular}

У сильно ослаблених соснових деревостанах частка дерев I та II категорій санітарного стану зменшується і разом становить $34,1 \%$, натомість збільшується частка дерев V і VI категорій санітарного стану до 11,6\%. У цих деревостанах уже утворюються біогрупи дерев 3 ознаками пошкодження короїдом верхівковим та іншими первинними стовбуровими шкідниками, зокрема златкою синьою сосновою (Phaenops cyanea (Fabricius, 1775)). У всихаючих і мертвих сосняках діють повноцінні осередки всихання внаслідок дії первинних і вторинних стовбурових шкідників. Отже, частка дерев I та II категорій санітарного стану становить 11,3 і 9,2 \%, а частка дерев V i VI категорій санітарного стану - 42,3 і 64,6 \% відповідно.

Також проведено розподіл усереднених часток дерев за категоріями санітарного стану сосняків, в яких здійснено санітарні рубки вибіркові. Як випливає з даних табл. 3, в ослаблених сосняках частка дерев I та II категорій санітарного стану становила разом 65,4 \%, а частка дерев V i VI категорій санітарного станутільки 0,3 \%. Залежно від санітарного стану соснових деревостанів частка дерев I та II категорій санітарного стану поступово зменшується, а частка дерев V i VI категорій санітарного стану - збільшується. Так, у сосно- 
вих деревостанах 3 дуже сильним ступенем пошкодження частка дерев I та II категорій санітарного стану разом становила 3,7 \%, а частка дерев V i VI категорій санітарного стану $-57,0 \%$.

Табл. 3. Розподіл дерев за категоріями санітарного стану у сосняках, де проводили СРВ

\begin{tabular}{|c|c|c|c|c|c|c|c|}
\hline \multirow{2}{*}{$\begin{array}{l}\text { № } \\
3 / \Pi\end{array}$} & \multirow{2}{*}{$\begin{array}{c}\text { Санітарний стан } \\
\text { деревостану }\end{array}$} & \multicolumn{6}{|c|}{$\begin{array}{c}\text { Частка дерев за категоріями } \\
\text { санітарного стану, \% }\end{array}$} \\
\hline & & I & II & III & IV & $\mathrm{V}$ & VI \\
\hline 1 & & 19,1 & 46,3 & 29,8 & 4,5 & 0,1 & 0,2 \\
\hline 2 & Сильн & 1,3 & 26,6 & 43,3 & 19,5 & 4,1 & 5,2 \\
\hline 3 & чий & 0,1 & 9,7 & 33,9 & 27,8 & 15,3 & 13,2 \\
\hline 4 & Мертвий & 0 & 3,7 & 16,0 & 23,4 & 7,5 & 49,5 \\
\hline
\end{tabular}

Наведені вище дані дають змогу зробити висновок, що санітарний стан у досліджених ділянках, в яких проведені СРВ, порівняно із сосняками, які зростають у кулісах і дрібноконтурних ділянках, є кращим. Але, беручи до уваги подальше погіршення їх санітарного стану, правомірно стверджувати, що не було отримано очікуваного оздоровчого ефекту від проведення СРВ у досліджених сосняках. Причиною цього є складність діагностування уражених дерев короїдом верхівковим на початковому етапі його заселення і розвитку. Треба наголосити, що санітарний стан залишених дерев після СРВ значно погіршувався під дією різкої зміни умов зростання, зокрема внаслідок істотного збільшення освітлення з аномально високими температурами повітря і одночасно - 3 кількістю опадів у вегетаційний період, нижчою за середню кліматологічну норму. Такі несприятливі погодні умови спричиняють нестачу живиці та зменшення опору дерев сосни шкідливим комахам, саме тому ці дерева за вегетаційний період, а часто за 50-70 діб, переходять з II-III до V-VI категорій санітарного стану. Також варто наголосити на тому, що чим менша повнота деревостану, яка залишилася після проведення СРВ, тим гостріше відбуваються наведені вище процеси.

\section{Висновки:}

1. Санітарні рубки вибіркові в осередках ксилофаговоофіостомового комплексу не дають очікуваного ефекту, і за один-два вегетаційні періоди санітарний стан цих соснових деревостанів значно погіршується.

2. Санітарний стан залишених соснових куліс та дрібноконтурних ділянок впродовж декількох вегетаційних періодів значно погіршується.

3.3 огляду на гостру дію ксилофагово-офіостомового комплексу потрібно внести зміни у чинні нормативні документи для ведення лісового господарства, зокрема: у Правила рубок головного користування (Pravyla rubok holovnoho korystuvannia, 2010) - під час рубок не залишати дрібноконтурних ділянок і вузьких куліс; у Санітарні правила (Sanitarni pravyla v lisakh Ukrainy,
2016) - під час проведення санітарних рубок суцільних збільшити повноту до 0,4.

\section{Перелік використаних джерел}

Anuchin, N. P. (1982). Lesnaia taksatciia. [Forest taxation]. Moscow: Lesnaia promyshlennost, 552 p. [In Russian].

Krasnov, V. P. (Ed.). (2011). Dovidnyk iz zakhystu lisu. [Forest protection reference book]. Kyiv: Eko-inform, 528 p. [In Ukrainian].

Krasnov, V. P., Tkachuk, V. I., \& Orlov, O. O. (2013). Dovidnyk spetsialista lisovoho hospodarstva. [Reference book of forestry specialist]. Zhytomyr - Novograd-Volynsky: Novograd, 436 p. [In Ukrainian].

Lisovyi, M. M., \& Chaika, V. M. (2008). Ekolohichna funktsiia entomolohichnoho bioriznomanittia. Fauna komakh-fitofahiv derevnykh i chaharnykovykh nasadzhen Lisostepu Ukrainy. [Ecological function of entomological biodiversity. Insect-phytophage fauna of forest and shrub plantations of the forest-steppe of Ukraine]. KamyanetsPodilsky: Aksioma, 384 p. [In Ukrainian].

Materialy. (1987). Normativno-spravochnye materialy dlia taksatcii lesov Ukrainy i Moldavii. [Normative and reference materials for the forest taxation of Ukraine and Moldova]. Kyiv: Urozhai, $560 \mathrm{p}$. [In Russian].

Meshkova, V. L. (Ed.). (2010). Metodychni rekomendatsii shchodo obstezhennia oseredkiv stovburovykh shkidnykiv lisu. [Methodical recommendations for the survey of stem pest foci in the forest]. Kharkiv: UkrNDILHA, 27 p. [In Ukrainian].

Nakaz. (2010). Pravyla rubok holovnoho korystuvannia (Nakaz №364 Derzhavnoho komitetu lisovoho hospodarstva vid 23.12.2009 roku). [The rules of the main use cuttings (Order № 364 of the State Forestry Committee dated December 23, 2009)]. Retrieved from: http://zakon2.rada.gov.ua/laws/show/z0085-10. [In Ukrainian].

Padii, M. M. (1993). Lisova entomolohiia. [Forest entomology]. Kyiv: USHA, 283 p. [In Ukrainian].

Pasternak, P. S. (Ed.). (1990). Spravochnik lesovoda. [Forester reference book]. Kyiv: Urozhai, 296 p. [In Russian].

Pravyla. (2016). Sanitarni pravyla $v$ lisakh Ukrainy (vneseni zminy postanovoiu KMU vid 26.10.2016 r., № 756). [Sanitary rules in forests of Ukraine (amended by the decree of the Cabinet of Ministers of Ukraine dated October 26, 2014, No. 756)]. Retrieved from: http://zakon3.rada.gov.ua/laws/show/756-2016-п/paran11\#n11. [In Ukrainian].

Rekomendatsii. (2017). Tymchasovi rekomendatsii shchodo provedennia pershocherhovykh zakhodiv u sosnovykh lisakh, poshkodzhenykh koroidamy. [Temporary recommendations for the implementation of priority measures in pine forests damaged by the bark beetles]. Retrieved from: https://rive.google.com/file/d/1dDCBLrsN0qg3tM3fMrf6ulLpJVv6DIXS/view. [In Ukrainian].

Shevchenko, S. V., \& Tciliurik, A. V. (1986). Lesnaia fitopatologiia. [Forest phytopathology]. Kyiv: Vyshcha shkola, 384 p. [In Russian].

SOU 02.02-37-476. (2006). Ploshchi probni lisovporiadni. Metod zakladannia. [SOU Forest test plots. Method of laying]. Kyiv: Minahropolityky Ukrainy, 32 p. [In Ukrainian].

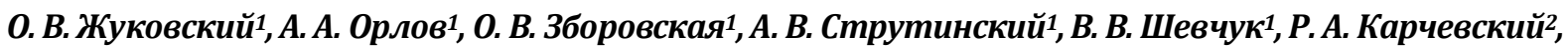
И. Т. Гулик ${ }^{1}$, А. В. Левковский 1

${ }^{1}$ Полесский филиал УкрНИЛХА им. Г. Н. Высоикого, с. Довжик, Украина ГП "Житомирское лесное хозяйство", г. Житомир, Украина

\section{САНИТАРНОЕ СОСТОЯНИЕ СОСНОВЫХ ДРЕВОСТОЕВ ПОСЛЕ ПРОВЕДЕНИЯ САНИТАРНЫХ РУБОК ВЫБОРОЧНЫХ, В КУЛИСАХ И МЕЛКОКОНТУРНЫХ УЧАСТКАХ В ОЧАГАХ ПОРАЖЕНИЯ КОРОЕДОМ ВЕРШИННЫМ}

Исследование проведено в Житомирском Полесье в течение 2017 г. Проанализировано санитарное состояние древостоев сосны обыкновенной в очагах поражения короедом вершинным после проведения санитарных рубок выборочных (СРВ), а также отдельно - в кулисах и мелкоконтурных участках. Учеты, измерения, описания на исследованных объектах проведены согласно общепринятым методикам лесоводства, лесной таксации и лесной энтомологии. Выявлено, что основным вредителем, который вызывает усыхание исследованных сосняков, являются короед вершинный. Продемонстрировано, что в сосновых кулисах и мелкоконтурных участках наибольшее количество обследованных древостоев - сильно ослабленные 
(58,5 \%); усыхающими оказались 29,2 \% участков; ослабленными - 7,7 \%, а мертвыми - 4,6 \%. Следует особо подчеркнуть, что среди исследуемых сосняков отсутствовали здоровые древостои. Установлено, что после проведения СРВ максимальным было долевое участие сильно ослабленных сосняков - 42,7 \%, что меньше по сравнению с соответствующим показателем для кулис и мелкоконтурных участков. Вместе с тем, долевое участие ослабленных насаждений было значительно больше после проведения СРВ - 21,3 \%, а мертвых - значительно меньше $(2,7$ \%) по сравнению с соответствующим показателем для кулис и мелкоконтурных участков. Сделан вывод о том, что санитарные рубки выборочные в очагах ксилофагово-офиостомового комплекса не дают ожидаемого эффекта, и за один-два вегетационные периоды санитарное состояние сосновых древостоев значительно ухудшается, как и санитарное состояние сосняков в кулисах и мелкоконтурных участках. Обосновано предложение о внесении изменений в действующие нормативные документы для ведения лесного хозяйства в связи с острым действием ксилофагово-офиостомового комплекса.

Ключевые слова: сосна обыкновенная; усыхание; стволовые насекомые-вредители; категория санитарного состояния; лесохозяйственные мероприятия.

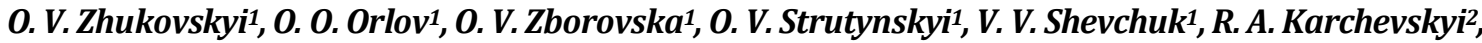 I. T. Hulyk ${ }^{1}$, O. V. Levkivskyi ${ }^{1}$ \\ ${ }^{I}$ Poleski branch of Ukrainian Research Institute of Forestry and Agroforestry named after Vysotsky, Dovzhik, Ukraine ${ }_{2}^{2}$ State Enterprise "Zhytomyr forestry", Zhytomyr, Ukraine}

\section{SANITARY STATUS OF PINE STANDS AFTER SELECTIVE SANITARY CUTTINGS, ON THE NARROW STRIPS AND SMALL-PLOT AREAS IN THE IPS ACUMINATUS POCKETS}

During 2017 in Zhytomyr Polissya the sanitary status of pine stands was investigated in the Ips acuminatus pockets after the selective sanitary cuttings, and separately - on the narrow strips and small-plot areas without selective sanitary cuttings. The records, measurements, and descriptions on the study objects were conducted according to generally accepted methods of forestry, forest taxation and forest entomology. It is revealed that the main pest which causes the drying out of studied pine stands was Ips acuminatus. It is demonstrated that in the pine narrow strips and small-plot areas the largest number of studied stands were strongly weakened $(58.5 \%)$; drying out $-29.2 \%$; the weakened $-7.7 \%$, and the dead $-4.6 \%$. It should be emphasized that there were no healthy pine stands among studied ones. It was determined that after the selective sanitary cuttings the maximum quota of studied stands were strongly weakened $-42.7 \%$, which was smaller compared to the corresponding index for the narrow strips and small-plot areas. At the same time, the quota of weakened pine stands was much higher after the selective sanitary cuttings $-21.3 \%$, and dead - much less $(2.7 \%)$ compared to the corresponding index for the narrow strips and small-plot areas. It was concluded that the selective sanitary cuttings in the xylophagous-ophiostomous complex pockets did not not provide the expected effect, and during one or two vegetation periods the sanitary status of pine stands significantly deteriorated, as well as the sanitary status of the pine stands in the narrow strips and small-plot areas. The reasons of this phenomenon are difficulties of diagnosing the affected trees with Ips acuminatus at the initial stage of its infusion and development. The proposal concerning introduction of changes to the current normative documents for forestry management was justified in connection with acute action of xylophagous-ophiostomous complex. As a whole, on our opinion, effective and balanced are Temporary Recommendations for carrying out priority measures in pine forests damaged by bark beetles, developed by a team of scientists of URIFFM under the leadership of prof. V.L. Meshkova. However, entered into force at the same time with the current Sanitary Rules with the higher status, they are not used in the practical forestry of Ukraine.

Keywords: Scotch pine; drying out; trunk harmful insects; category of sanitary status; forestry activities. 